\title{
Are Close of Pleadings now Irrelevant? \\ An Evaluation of the Impact the Nkala Judgment \\ has on Litis Contestatio
}

MS Khan*

\section{P.E.R}

Pioneer in peer-reviewed, open access online law publications

Author

Muhammed Siraaj Khan

Affiliation

North-West University, South Africa

Email

Muhammed.Khan@nwu.ac.za

Date Submission

27 July 2018

Date Revised

13 February 2019

Date Accepted

20 February 2019

Date published

19 March 2019

Editor Prof O Fuo

How to cite this article

Khan MS "Are Close of Pleadings now Irrelevant? An Evaluation of the Impact the Nkala Judgment has on Litis Contestatio" PER / PELJ 2019(22) - DOI

http://dx.doi.org/10.17159/17273781/2019/v22i0a5397

Copyright

DOI

http://dx.doi.org/10.17159/1727-

3781/2019/v22i0a5397

\section{Abstract}

The position regulating close of pleadings in South African law of civil procedure has for a long time been unchallenged. However, the court in Nkala v Harmony Gold Mining Company Limited 20165 SA 240 (GJ) developed the common law to allow for the transmissibility of claims for general damages to the deceased's estate even if pleadings have not reached the stage of litis contestatio. The argument is that while the need for the development for the common law is recognised, the minority opinion should be the preferred approach. The majority held that the common law should be developed to allow all claims for general damages to be transmissible to the deceased's estate even if the stage of litis contestatio has not been reached. This note posits that the points raised by the minority opinion are of sufficient magnitude to prevent the immediate wholesale development of the common law. Detailed legal argument specifically addressing the development of the common law as a whole in this context, as well as the knock-on effects of the same were not ventilated, and as such the majority judgment can be viewed as premature. The paper provides an analytical and critical view of the judgment.

\section{Keywords}

Civil procedure; litis contestatio; class action; development of the common law; delict. 


\section{Introduction}

Litis contestatio has its roots in Roman law. ${ }^{1}$ When a Roman citizen wished to initiate litigation, he was required to access a magistrate who had the power of iurisdictio, and the magistrate would decide if the litigant had a case that warranted being taken further for the purpose of trial. ${ }^{2}$

The stage of the procedure which took place before the magistrate, and terminated when issue was joined (litis contestatio) was known as the procedure in iure. ${ }^{3}$

The concept of litis contestatio has been likened to the making of a contract between parties wherein they would settle the terms according to which

... they submitted themselves to the decision of the judge in lieu of their erstwhile rights. ${ }^{4}$ Litis contestatio is considered 'critical' as it is the moment when parties 'joined issue'.

From this moment onward the plaintiff's right was held to be "consumed" in Roman law. ${ }^{5}$ In modern times litis contestatio is known as "close of pleadings". 6 Van Zyl observes that one of the fundamental consequences of litis contestatio is that the litigant (instituting the action), cannot later bring legal proceedings against a defendant based on the same facts and cause of action. ${ }^{7}$ Prior to the Nkala $v$ Harmony Gold Mining Company ${ }^{8}$ judgment, the position regulating close of pleadings was as follows: "If a plaintiff who was claiming for non-pecuniary damages for pain and suffering died before litis contestatio, his claim died with him". ${ }^{9}$ However, should the plaintiff die after litis contestatio, then in such circumstances the claim would be transmitted to the plaintiff's estate. Jones and Buckle ${ }^{10}$ make reference to Potgieter $v$ Sustein (Edms) Bpk, ${ }^{11}$ which held that the rules of court that govern close of pleadings do "... not merely create a rebuttable presumption

\footnotetext{
* $\quad$ Muhammed Siraaj Khan. LLB, LLM (University of KwaZulu-Natal), Attorney of the High Court of South Africa. Lecturer, Faculty of Law, North-West University (Potchefstroom Campus), South Africa. E-mail: 30448093@nwu.ac.za.

See for example Thomas Textbook of Roman Law 104.

Van Zyl History and Principles of Roman Private Law 365.

Van Zyl History and Principles of Roman Private Law 365.

Thomas Textbook of Roman Law 104.

Jolowicz Historical Introduction 187. The author explains "consumed" to mean "even if judgment was not obtained, no fresh action could be brought on the same claim". See for example Theophilopoulos et al Fundamental Principles 302.

Van Zyl History and Principles of Roman Private Law 378.

Nkala v Harmony Gold Mining Company Limited 20165 SA 240 (GJ) (hereafter Nkala).

$9 \quad$ Peté et al Civil Procedure 222.

10 Jones and Buckle Civil Practice of the Magistrates' Courts HCR 29A-1.

11 Potgieter $v$ Sustein (Edms) Bpk 19902 SA 15 (T).
} 
that pleadings were closed but in fact constituted a substantive rule of adjectival law".

The position prior to the Nkala judgment was thus clear: claims for damages for personal injury were transmissible on the death of the party only after litis contestatio.

The circumstances when pleadings are deemed closed are clearly outlined in the rules of court. Rule 29 of the Uniform Rules of Court ${ }^{12}$ provide that pleadings will be considered closed:

(a) if either party has joined issue without alleging any new matter, and without adding any further pleading;

(b) if the last day allowed for filing a replication or subsequent pleading has elapsed and it has not been filed;

(c) if the parties agree in writing that the pleadings are closed and such agreement is filed with the registrar; or

(d) if the parties are unable to agree as to the close of pleadings, and the court upon the application of a party declares them closed.

Peté et al point out that Rule 29 of the Uniform Rules of court is "subject to the parties' entitlement to amend pleadings in terms of Rule $28 "{ }^{13}$ They note that "minor or immaterial amendments would not result in fresh litis contestatio". ${ }^{14}$ It appears that the wording of Rule 29 (or Magistrates' Court Rule 21A) of the Uniform Rules of Court is in conformity with common law in that it does not alter the common law consequences of litis contestatio. ${ }^{15}$

In Nkala the court had to make a decision with regard to the development of the common law position governing the transmissibility of general damages, in the event that the plaintiff/applicant passes away prior to the matter's reaching the stage of litis contestatio. ${ }^{16}$ This note explores the

12 The Magistrates Court Act 32 of 1944 Rule 21 A provides a virtually identically worded section.

13 Peté et al Civil Procedure 223, fn 200.

14 Peté et al Civil Procedure 223, fn 200.

15 There is potential for the abuse of Rule 28 of the Uniform Rules of Court, which would have an impact on litis contestatio, in the sense that a party may constantly make amendments to their pleadings, and this would essentially amount to pleadings being opened again. See Peté et al Civil Procedure 223, fn 200, where reference is made to KS v MS 20161 SA 64 (KZN), which held that minor or insignificant changes would "not result in fresh litis contestatio". Nkala para 176. 
consequences of the Nkala judgment through a consideration of the legal and practical issues surrounding close of pleadings and the effect that this has had on the common law position, by examining the majority and minority opinions in that case. In this note I will take the position that the minority judgment should be followed instead of the majority judgment. To make my argument I will discuss the facts of the judgment and to this effect I will provide a brief summary of the key points. This will be followed by a brief overview of the legislation governing close of pleadings, and the development of the common law. Finally, the minority and majority judgments will be evaluated and I will explain why I believe that the minority judgment is better.

\section{Facts}

The Nkala case involved mineworkers seeking compensation from the gold mines at which they were employed. The basis of the mineworkers' claim was that they contracted Silicosis or Tuberculosis (TB) due to the failure of the mining companies to provide adequate measures to prevent this. The action involved the miners' dependants' seeking compensation for general damages (which were incurred by the applicants, and who subsequently passed away during the action) as well. The case dealt with multiple legal issues, including class action, the law of delict, costs, litis contestatio, and the development of the common law. ${ }^{17}$

While it is outside the scope of the intended discussion, it necessary to very briefly provide some insight as to what Silicosis and TB are (after all they are central to the applicants' case), as well as an overview of what the other legal issues were. Silicosis is caused exclusively by the miners' inhaling crystalline silica dust (which is, of course, a consequence of working in the mines). Silicosis is an incurable disease. TB, on the other hand, is a lung disease which can be treated. The mineworkers admitted that TB is not contracted by exposure to the silica dust present at the mines, but averred rather the exposure to the dust poses a risk for the development of TB. The judgment then turned to look at the issue of class action and the logistics of the same. Ultimately the Court concluded that "it is in the interest of justice that the matter be dealt with in a single class action hearing" (Nkala para 180). The Court made reference to several affidavits from the applicants which portrayed a sad story of how the miners had to wake up in the early hours of the morning, how they were exposed to constant physical and emotional abuse, and how they were generally subjected to cruel treatment at the hands of their managers (para 180). The miners further outlined how the masks that they were provided with were insufficient for their purpose (that of preventing the dust particles from being inhaled). The mineworkers further sought an order from the court declaring that any claim for general damages that a mineworker brought or might wish to bring against any of the mining companies subject to the litigation was transmissible to his estate, should such a miner pass away prior to the proceeding reaching the stage of litis contestatio. 
The issue of close of pleadings is of significance, because if the miners passed away before the close of pleadings, then their claims would die with them. This would result in their families receiving no benefit, however, if they passed away after pleadings were deemed to be closed, then the claim would be transferred to the deceased's estate.

\section{Majority opinion on the transmissibility of general damages}

The majority opinion was that claims for general damages should be transmissible in all instances, regardless of whether the stage of litis contestatio has been reached or not. ${ }^{18}$ The common law was thus developed accordingly. Mojapele DJP and Vally $\mathrm{J}$ for the majority considered the history of litis contestatio. They noted that in Roman law the transmissibility of certain claims to or against heirs of a deceased estate were prevented. ${ }^{19}$ "Claims in rem could be transmitted, while claims in personam could not." 20 The court further pointed out that a claim for an iniuriarum (actio iniuriarum - a claim for relief pursuant to a wrongful and intentional damage to personality) was not transmissible to or against the heirs.

An exception to this rule was noted, which is that, regardless of whether the claim was in rem or in personam, once litis contestatio had taken place "the death of either party in no way prevented the continuation of proceedings by or against his heir". ${ }^{21}$

The majority pointed out that this Roman Dutch rule (which followed Roman Law) had been transposed into South African Law, and that the position had remained unchanged since $1880 .{ }^{22}$ The court correctly went on to say that the prevailing conditions in South Africa with regard to social, economic and legal factors were vastly different from those that existed in the times of early Roman law. ${ }^{23}$ We now have a supreme Constitution which promotes the values of equality and human dignity, and the development of the common law should take place in the light of such values. ${ }^{24}$

Nkala para 215.

Nkala para 180.

Nkala para 180.

Nkala para 180.

Nkala paras 181-184.

Nkala para 184.

See ss 9 and 10 of the Constitution of the Republic of South Africa, 1996 (the Constitution) respectively. 
The different types of damages that a party may claim for need to be explored in order to fully understand the impact of the Nkala judgment. The two different types of damages are patrimonial damages and nonpatrimonial damage. Often, non-patrimonial damages are referred to as general damages, and they include claims for the loss of amenities of life, disfigurement, and pain and suffering. ${ }^{25}$ Such claims are relatively straightforward and do not call for the development of the common law, as they will be allowed to be transmitted to the deceased's estate even if pleadings have not reached the stage of litis constestatio. Claims in the other class are difficult to calculate ${ }^{26}$ because (it is argued) they are of a personal nature and should not be transferrable. The present position regulating close of pleadings (in relation to the above-mentioned categories of damages) was articulated in detail by the court:

In other words, the executor can sue for any patrimonial loss the deceased suffered before his death as well as the funeral expenses which is a patrimonial loss suffered after death, and the dependants can sue for any patrimonial loss they themselves will suffer as a result of the premature death of their financial provider or breadwinner. ${ }^{27}$

The court further noted that "neither can sue for any personal injury such as pain and suffering, loss of amenities of life or disfigurement (general damages) the deceased suffered prior to his death". ${ }^{28}$ The court took note of an exception to the rule, to the effect that where the deceased had already instituted action and the proceedings had reached the stage of litis contestatio before his/her death, and the claim was continued by the executor of his/her estate, "the claim for the personal injuries does not abate". ${ }^{29}$ In such circumstance the law allows for the claim for general damages to be transmitted to the estate. ${ }^{30}$ The court observed that

... the basis for the exception is exactly the same as that under the early Roman law, which provides that the rights of the plaintiff were defined and 'frozen', at the moment the stage of litis contestatio was reached. ${ }^{31}$

In such circumstances, the executor merely steps into the position of the deceased. ${ }^{32}$ The issue as to when the stage of litis contestatio is reached in the modern law (according to the court) is not so straightforward. ${ }^{33}$

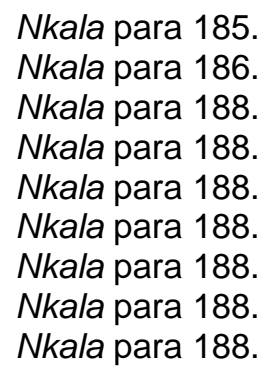


Guidance as to when pleadings are closed can be found in Rule 29 of the Uniform Rules of Court (or Magistrates' Court Rule 21A). ${ }^{34}$

While the Uniform Rules of Court and the Magistrates' Court Rules are relatively straight-forward, there are exceptions. Normally pleadings will be deemed closed if the dies allowed for replication elapse without the replication being served. ${ }^{35}$ Even though pleadings are closed, they are considered re-opened in the event that a party effects an amendment. It is observed by the court that the reason the rule exists (the rule that a claim for general damages is not be transmissible to the deceased's estate) is that "general damages are personal to the claimant". ${ }^{36}$ The court held that this rule (which is embedded in common law) is outdated. The mineworkers' submission was that this rule infringes on the provisions of the Bill of Rights, and that the application of the rule had the potential to cause immense injustice not only to them but to their heirs as well.

There was consensus between both the majority and the minority judgments that the common law does require development in this regard. However, there was no agreement as to what this development should entail exactly.

The majority judgment held that there was a constitutional imperative to develop the common law, because the arguments advanced by the mineworkers were quite forceful. ${ }^{37}$ In essence the mineworkers submitted that their right to bodily integrity ${ }^{38}$ and freedom and security of person ${ }^{39}$ were being violated by the common law in preventing their claims to transmit to their estates.

Another important point that was submitted by the applicants was that the common law position infringed section 9 of the Constitution (which provides for the equal treatment of all persons) because it arbitrarily differentiated between survivor's pre-litis contestatio and post litis contestatio. ${ }^{40}$ The rights of terminally ill miners were being violated in this regard, as many of them would probably not survive until the action was finalised. These persons and their heirs would be forced to forfeit a sound claim solely because they had passed away before litis contestatio. ${ }^{41}$ It was held that should the claim for

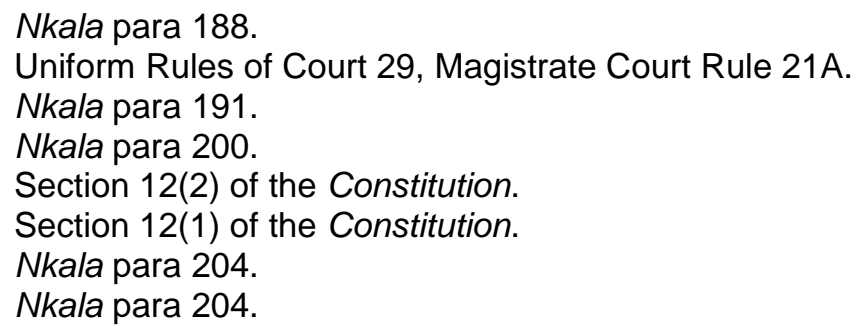


general damages not be allowed to be transmitted to the miners' estates (just because such miners passed away prior to the close of pleadings) in these circumstances, it would amount to substantial injustice. ${ }^{42}$ The system of close of pleadings could potentially be abused. A party (such as the mining companies, in this instance) could amend their pleadings at any time, and this would result in pleadings being re-opened, the consequence of which might mean the heirs' losing their claims on this technicality. ${ }^{43}$ In this light, the majority held that: "... if the law is not developed, then in this case it would have failed the weak individuals and benefitted the powerful corporates". ${ }^{44}$ Ultimately it was held that the common law has to be developed such that claims for general damages are transmissible to the estate or executor of a deceased mineworker despite the fact that the litigation has not reached a stage when pleadings are deemed to be closed at the time of the death of the deceased..$^{45}$

The majority judgment took the matter a step further when it held that the development of the common law should not be limited to instances where the plaintiff has passed away prior to litis contestatio, but that it should be applied in instances where a defendant or potential defendant had passed away prior to litis contestatio, as the principles that applied to the plaintiff should apply mutatis mutandis to the defendant as well. ${ }^{46}$

\section{Minority opinion on transmissibility of general damages}

Windell $\mathrm{J}$ dissented from the majority judgment on the issue of the transmissibility of general damages prior to litis contestatio. ${ }^{47}$ The judge pointed out that the relief sought by the miners was for members of the class action only, and that "transmissibility of general damages in all actions generally was neither dealt with nor is it relevant for the purposes of deciding this case". ${ }^{48}$ Windell $\mathrm{J}$ further correctly made reference to the fact that the court was not privy to proper arguments in this respect, and that a judgment declaring that general damages are always transmissible to the deceased's estate could have "far reaching consequence". ${ }^{49}$ The minority judgment held that the common law should be developed in relation to class action

Nkala para 213.
Nkala para 213.
Nkala para 213.
Nkala para 215.
Nkala para 216.
Nkala para 231.
Nkala para 234.
Nkala para 234. 
proceedings only. ${ }^{50}$ Windell $\mathrm{J}$ was in favour of an incremental development of the common law. ${ }^{51}$ It was held that the "knock-on effect" must be taken into consideration: a declaration that general damages will always be transmissible to a deceased's estate even prior to litis contestatio was of considerable gravity, as it affected other branches of law. ${ }^{52}$ Particular reference was made to Road Accident Fund matters. The learned Judge suggested that due to the volume of claims for general damages being transmitted to the deceased's estate, the viability of the Road Accident Fund would be placed risk if the law were developed as per the majority judgment. ${ }^{53}$ This was an example of further information being required to fully understand the consequences of developing the common law.

\section{An evaluation of the Nkala judgment}

Ultimately the question is whether the common law has been developed correctly. The two judgments identified the need for the common law to be developed, but they adopted slightly different stances with regard to the issue.

Section 39 of the Constitution provides:

(1) When interpreting the Bill of Rights, a court, tribunal or forum-

(a) must promote the values that underlie an open and democratic society based on human dignity, equality and freedom;

(b) must consider international law; and

(c) may consider foreign law.

(2) When interpreting any legislation, and when developing the common law or customary law, every court, tribunal or forum must promote the spirit, purport and objects of the Bill of Rights.

In line with the above constitutional provision, there has always been " a need for the law to develop to respond to contemporary development". ${ }^{54}$ However, it appears that there are no clear-cut guidelines with regard to the framework for developing the common law in certain cases. ${ }^{55}$ Davis submits

Nkala para 241.

Nkala para 243.

Nkala para 234.

Nkala para 234.

Davis 2014 Stell LR 3.

Davis 2014 Stell $L R$ 10. The cases referred to in the article are: Lee $v$ Minister of Correctional Services 20132 SA 144 (CC), and Maphango v Aengus Lifestyle 
that an "... examination of the normative framework of the Constitution as divined from the spirit, purports and objectives of the Bill of Rights ...is required". 56

In discussing this principle in the context of the Lee case, Davis states that the finding would have made it clear that a development of the common-law rule which is used to ascertain factual causation was needed. ${ }^{57}$ Likewise such a need (of course in relation to claims for general damages instead of factual causation) was identified in the Nkala case. The question that then arises is which judgment (if any) is preferred?

Windell $\mathrm{J}$ was cautious in restricting the development of the common law with regard to the transmissibility of general damages prior to litis contestatio to class action only, based on the following grounds: that proper argument in favour of the development of the common law in general had not been made, and secondly that such a judgment would have an effect on other branches of law (specific reference was made to succession and Road Accident Fund matters). ${ }^{58}$ Research with regard to the exact figures that would need to be paid out by the Road Accident Fund in the light of the development declared by the majority judgment needs to be performed.

The counter argument would involve asking a question: even if the figures turned out to be drastic, would this be sufficient reason to continue the injustice that the majority judgment had identified? If the general damages due (to the now deceased class member) were to be denied simply because he succumbed to his disease prior to the stage of litis contestatio, this would perpetuate the injustice. ${ }^{59}$

The way forward could possibly involve a section 36 (limitations clause) inquiry, weighing up (for example) the right to freedom of security and bodily integrity, and equality against the rights of victims of motor vehicle collisions to claim compensation for injuries. It is my opinion that the minority judgment should be the preferred method of developing the common law until such time that a better researched argument is presented to the Courts for the development of the common law to allow for the transmissibility of general

Properties (Pty) Limited 20123 SA 531 (CC). (Section 39 of the Constitution does provide for the development of the common law.) 
damages in all instances where litigation has started but litis contestatio has not been reached.

It is recognised that time was of importance in the Nkala case, and the Court was under pressure to resolve the issue. However, it is submitted that the research required could have been presented in a short period of time. The suggestion here is that the matter should have been postponed for a short period to allow Counsel to advance argument for and against the development of the common law in all instances. In the absence of this information, the decision of the majority judgment could be viewed as a relatively hasty decision. The minority judgment would have provided the necessary relief for the mineworkers without threatening the financial sustainability of the Road Accident Fund, and would have opened the door for the further development of the common law (if necessary) in future, after proper argument had been advanced addressing the issue.

\section{Conclusion}

It is clear that the common law position relating to the transmissibility of general damages pre the Nkala judgment required development. The majority judgment was adamant that the law must be developed in all such instances to allow for the transmissibility of a claim (provided legal proceedings have commenced). The minority judgment was of the view that the law should be developed to allow the transmissibility of claims for general damages prior to litis contestatio, but that this should be restricted to class actions. The minority judgment raises pertinent points against the majority finding, and it is submitted that these should (and probably will) be addressed when the matter is eventually heard on appeal. As it stands, even if pleadings are not closed, claims for general damages will be transmissible to a deceased's estate.

To answer the question raised by the title of this note, the close of pleadings is not completely irrelevant once litigation has commenced. It still impacts on the logistics of proceedings, such as applying for a trial date. ${ }^{60}$ However, in terms of the transmissibility of claims for general damages to the deceased's estate, according to the majority opinion in the Nkala judgment, it seems that the close of pleadings is irrelevant for that purpose if litigation has already commenced.

60 See Magistrates' Court Rule 22(1), which provides that the plaintiff is to deliver a notice of set-down within 15 court days after the close of pleadings. 


\section{Bibliography}

\section{Literature}

Davis 2014 Stell LR

Davis DM "Where is the Map to Guide Common-law Development?" 2014 Stell LR 3-14

Jolowicz Historical Introduction

Jolowicz HF Historical Introduction to the Study of Roman Law $2^{\text {nd }}$ ed (Cambridge University Press London 1967)

Jones and Buckle Civil Practice of the Magistrates' Courts Jones PST and Buckle HO The Civil Practice of the Magistrates' Courts in South Africa $10^{\text {th }}$ ed (Juta Cape Town 2011)

Peté et al Civil Procedure

Peté S et al (eds) Civil Procedure: A Practical Guide $3^{\text {rd }}$ ed (Oxford University Press Cape Town 2017)

Theophilopoulos et al Fundamental Principles

Theophilopoulos C et al (eds) Fundamental Principles of Civil Procedure $3^{\text {rd }}$ ed (LexisNexis Durban 2015)

Thomas Textbook of Roman Law

Thomas JAC Textbook of Roman Law $2^{\text {nd }}$ ed (Juta Cape Town 1976)

Van Zyl History and Principles of Roman Private Law

Van Zyl DH History and Principles of Roman Private Law (Butterworths Durban 1996)

\section{Case law}

KS v MS 20161 SA 64 (KZN)

Lee v Minister of Correctional Services 20132 SA 144 (CC)

Maphango v Aengus Lifestyle Properties (Pty) Limited 20123 SA 531 (CC)

Nkala v Harmony Gold Mining Company Limited 20165 SA 240 (GJ)

Potgieter v Sustein (Edms) Bpk 19902 SA 15 (T) 


\section{Legislation}

Constitution of the Republic of South Africa, 1996

Magistrates Court Act 32 of 1944 (and Rules)

Superior Courts Act 10 of 2013 (and Rules)

\section{List of Abbreviations}

Stell LR

TB
Stellenbosch Law Review

Tuberculosis 